\title{
Life table of Hypothenemus bampei (Ferrari) in relation to coffee berry phenology under Colombian field conditions
}

\author{
Ramiro Ruiz-Cárdenas ${ }^{1,2 *}$; Peter Baker ${ }^{3}$ \\ ${ }^{1}$ Centro Nacional de Investigaciones de Café - A.A. 2427 - Manizales, Caldas - Colombia. \\ ${ }_{3}^{2} U F M G$ - Depto de Estatística - C.P. 702 - 31270-901 - Belo Horizonte, MG - Brasil. \\ ${ }^{3}$ CABI Bioscience, UK Centre, Bakeham Lane, Egham, Surrey TW20 9TY, United Kingdom. \\ *Corresponding author < ramiro@est.ufmg.br>
}

\begin{abstract}
The overlap of generations of coffee berry borer (CBB), Hypothenemus hampei (Ferrari) under field conditions in countries like Colombia hinders the construction of life tables by the sampling of natural populations. In this paper, a field methodology to carry out regular measurements of CBB cohorts inside coffee berries of different ages until harvest, both in coffee trees and in infested berries placed on the ground, is developed and used to compare the life history parameters of CBB. Populations with berries at six ages in three experimental stations (without CBB control) and in a commercial farm in Colombia (with chemical CBB control regularly carried out) were used. The duration of the pre-oviposition period as well as the mortality and survival rates of founder females and the proportion of founders leaving infested berries were strongly influenced by the consistency of berries, with optimum conditions for CBB reproduction as from 120-150 days after flowering. No differences were found between stations for the number of CBB developmental stages; but they had larger values than the commercial farm. The latter also had more than twice the average rate of founders leaving infested berries recorded in the stations. Survival functions (cumulative probabilities of survival) for the pest differed among treatments and between the plant and ground micro-environments. Age of berries at infestation was positively related to the intrinsic rate of increase of borer population; whilst generation time and doubling time were inversely related. No differences were found between sites for the main demographic parameters of the pest.
\end{abstract}

Key words: coffee berry borer, population parameters, integrated pest management

\section{Tabela de vida de Hypothenemus hampei (Ferrari) em relação à fenologia do fruto de café, sob condições de campo, na Colômbia}

\begin{abstract}
RESUMO: A superposição de gerações da broca do café, Hypothenemus hampei (Ferrari) em condições de campo em países como a Colômbia dificulta a confecção de tabelas de vida pela amostragem de populações naturais. Desenvolveu-se uma metodologia de campo para realizar medições regulares de coortes da broca em frutos de café de diferentes idades até a colheita, tanto nas plantas quanto em frutos infestados colocados no solo. O método é usado para comparar parâmetros populacionais da praga em frutos de seis idades, em três estações experimentais (sem controle da praga) e em uma fazenda comercial (com controle químico da praga), na Colômbia. A duração do período de pre-oviposição, assim como as taxas de mortalidade e sobrevivência das fêmeas fundadoras e a proporção de fêmeas fundadoras que abandonaram frutos infestados foram fortemente influenciadas pela consistência dos frutos, com condições ótimas para a reprodução da praga a partir de 120-150 dias depois da floração. Não houve diferenças entre estações para o número de estágios de desenvolvimento da praga, mas os valores nestas foram maiores que na fazenda comercial. Esta última teve uma taxa de frutos abandonados duas vezes maior que a registrada nas estações. As funções de sobrevivência (probabilidades acumuladas de sobrevivência) da broca foram diferentes entre tratamentos e entre os micro-ambientes planta e solo. A idade dos frutos na infestação foi positivamente correlacionada com a taxa intrínseca de crescimento das populações da broca, enquanto o tempo entre gerações e o tempo de duplicação da população estiveram inversamente relacionados. Não houve diferenças entre sítios para os principais parâmetros demográficos da praga.

Palavras-chave: broca do café, parâmetros populacionais, manejo integrado de pragas
\end{abstract}

\section{Introduction}

The importance of the coffee berry borer (CBB), Hypothenemus hampei (Ferrari), as the major coffee pest in worldwide coffee production has been recognized through numerous studies (Damon, 2000; Jaramillo et al., 2006). The pest was registered for the first time in Co- lombia in 1988 and it is present nowadays in more than 800 thousand hectares (about $90 \%$ of the planted area). It has been estimated that the costs of borer control in Colombia are around $9 \%$ of the total costs of coffee (Coffea arabica) production (Duque-Orrego et al., 2002). Despite this importance, there is a lack of research for this pest carried out under field conditions. As a result

Sci. Agric. (Piracicaba, Braz.), v.67, n.6, p.658-668, November/December 2010 
there are insufficient data on population parameters, which are necessary to guide the design of an efficient integrated management program for the pest.

Coffee plantations in Colombia have two main flowering periods during the year in most coffee growing regions, but there can be minor flowerings at other times, due to the combination of intrinsic and external conditions (Arcila-Pulgarin et al., 1993; Camayo-Vélez and Arcila-Pulgarin, 1997) and consequently, coffee trees have ripe berries almost all the year. This situation, added to the long period that berries stay on the trees (32 weeks on average) and to the extended oviposition period of CBB females, leads to many overlapping cohorts, making it difficult to study the life history of the pest under field conditions by the sampling of natural populations. Measurement of CBB population parameters such as growth and natural death rates is particularly difficult, since all developmental stages of the $\mathrm{CBB}$ can be found at the same time.

Hence the main aim of this research was to develop a field methodology that would allow us to carry out regular measurements of $\mathrm{CBB}$ cohorts inside the coffee berries until harvest and to compare the life history parameters of $\mathrm{CBB}$ populations under field conditions on berries of developmental stages, both on coffee trees and in infested berries placed on the ground. Additionally, we wanted to collect quantitative data about population dynamics of CBB as input for a simulation model, to guide effective management decisions for the control of this pest.

\section{Material and Methods}

Experiments were carried out from January to December 1995 simultaneously in three experimental field stations located in the central coffee producing region in Colombia: La Catalina (4⿳⺈冂八 $\left.45^{\prime} \mathrm{N}, 7^{\circ} 45^{\prime} \mathrm{W}\right)$, Supía

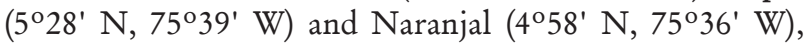
and in a commercial farm $\left(4^{\circ} 59^{\prime} \mathrm{N}, 7^{\circ} 35^{\prime} \mathrm{W}\right)$. All of these places had similar characteristics for both climate and altitude $(1,310$ to $1,400 \mathrm{~m}$ a.s.l., average temperature between $20.7^{\circ} \mathrm{C}$ and $21.6^{\circ} \mathrm{C}$; relative humidity from 76 to $79 \%$; precipitation between 1,906 and $2,370 \mathrm{~mm} \mathrm{year}^{-1}$ ). The reason for choosing similar sites was to test if sites with similar weather conditions would lead to similar development of CBB populations or whether microclimate or other factors could have a significant influence on the population dynamics of the borer. In each location a plot of coffee var Colombia was selected; the characteristics of these plots are summarized in Table 1.

To establish the cohorts of berries to perform the artificial CBB infestations, 1,200 coffee branches were selected in each plot, from coffee trees chosen at random. The selected branches were located in the middle part of the trees, and up to four branches were marked on the same coffee tree. The selection occurred after the identification of the main flowering period in each plot, with the branches being marked within two days after anthesis. On these branches, berries that had already formed as well as flowers where anthesis had not occurred were eliminated.

With identifiable cohorts of berries thus established, artificial infestations with adult CBB females were carried out for the field station replicates on berries of seven known ages starting at 60 days after flowering (DAF) and then every 30 days to $240 \mathrm{DAF}$, except for the fifth treatment (infestation at $180 \mathrm{DAF}$ ) in all experimental stations and the sixth and seventh treatments (210 and 240 DAF) in Naranjal station. Infestations on the commercial farm were done only at 90,120, 150 and 180 DAF. Conventional infestation methodology with entomological sleeves of $20 \mathrm{~cm}$ diameter and $40 \mathrm{~cm}$ long were used; they were installed around each selected branch and 200 adult CBB females were released inside. Sleeves were removed $48 \mathrm{~h}$ after infestation. In order to identify different cohorts when sampling were carried out, bored berries were individually marked by tying threads of different colors to the peduncle of each berry.

Adult CBB females used to infest the coffee berries in the different treatments were collected from large walk-in emergence cages containing thousands of field infested berries which were previously sprayed with water to stimulate emergence. To ensure healthy and vigorous stocks of $\mathrm{CBB}$, only adults of $\mathrm{CBB}$ that displayed active flight were collected.

No biological or chemical control of the pest was carried out on the stations during the experimental period in order to allow the natural development of borer populations. In contrast, $\mathrm{CBB}$ control was carried out in the commercial farm replicate, which consisted of generalized sprays with endosulfan $\left(5 \mathrm{cc} \mathrm{L}^{-1}\right.$ and $250 \mathrm{~L}$ $\left.\mathrm{ha}^{-1}\right)$ at $85 \mathrm{DAF}$ and with Beauveria bassiana $\left(1 \times 10^{9}\right.$ conidia tree $\left.{ }^{-1}\right)$ at $90 \mathrm{DAF}$, with additional localized en-

Table 1 - Characteristics of the selected coffee plots.

\begin{tabular}{lccccc}
\hline Location & Age of trees & Planting distance & Number of trees & Topography & Degree of shade \\
\hline La Catalina & years & $\mathrm{m}$ & & & \\
Supía & $2^{*}$ & $1.2 \times 1.5$ & 3200 & Wavy & Direct sunlight \\
Naranjal & $1^{*}$ & $1 \times 1.8$ & 2500 & Inclined & Slight shade \\
El Prado & 5 & $1 \times 12 \times 1$ & 2000 & Flat & Direct sunlight \\
\hline
\end{tabular}

*First "zoca" 
dosulfan sprays at 117, 137 and 165 days after the marked flowering, all carried out by the farmer.

Sampling was conducted daily up to seven days after infestation to determine the beginning of oviposition period, and then every seven days until 270 days after flowering. On each site and for each sampling date 50 infested berries were taken per treatment and placed on plastic containers previously identified, which were transported to the laboratory for dissection and to record the developmental stages of the borer under a stereomicroscope (10X). Numbers of live and dead adult CBB females were also recorded. Dead borers recorded at each sampling date that did not show visible signals of entomopathogenic fungi were individually placed into small vials with humidified absorbent paper. Subsequently, the percentage of borers with visible mycelia of fungi was determined after seven days. This information was taken into account when trying to explain the natural mortality factors of the pest.

Berry moisture content was measured before infestations and on every sampling date, using 50 berries from the marked branches that had not been attacked by the borer after artificial infestations. This sample was divided in two groups of 25 berries; each group was weighed and placed in the stove at $80^{\circ} \mathrm{C}$ until constant weight, and weighed again.

A third of all the infested berries on each treatment were randomly removed from the trees and placed on the ground to simulate a common field situation, where at least half of the CBB population is found in fallen berries under the coffee trees (Teixeira et al., 2006). Berries infested at 60,90 and $120 \mathrm{DAF}$ were left on the trees for 14 days before transfer to the ground, while berries infested at 150, 210 and 240 DAF were left on the trees for seven days to allow the establishment of the insect into the endosperm. Berries placed on the ground were protected with coarse mesh wire cages of $30 \times 30 \times 5 \mathrm{~cm}$, and without any coverage, which, according to a previous study, allow a normal development of CBB populations in this micro-environment. These ground berries were sampled with a similar frequency to those on the trees; the sample size was also the same.

Relative humidity and temperature were continuously recorded using thermo-hygrographs located in the middle of each plot. Daily precipitation records were also taken from the meteorological stations located at each experimental station.

The Lifetest procedure of the statistical package SAS (SAS Institute, 1989) was used to construct life tables according to the methodology described in Lee and Wang (2003). The following parameters were estimated based on values of age $(X)$, age-specific survival rate $(l x)$ and age-specific fecundity rate $(m x)$ :

net reproductive rate: $R o=\sum l x . m x$;

mean generation time: $T=\Sigma(l x . m x . X) / \sum(l x . m x)$;

intrinsic rate of natural increase $(r)$, calculated from Lotka equation (Dublin and Lotka, 1925): $\Sigma l x . m x \cdot e^{-r(x+0.5)}=1$. The initial value for $r$ was obtained through an iteration process starting from an analytical approximation for $r$ given as $r=$ $\operatorname{Ln}(R o) / T$ (Rabinovich, 1980; Carey, 1993); finite rate of increase: $\lambda=e^{r}$; doubling time: $D T=\operatorname{Ln} 2 / r$.

We define an average duration of egg stage because the frequency of sampling in this experiment would not allow us to know exactly the duration of each developmental stage of the borer. A regression equation of incubation period on mean temperature was fitted based on data of Bergamin (1943). Applying this equation to the recorded temperatures in the four localities of the present study, an average value of 8.9 days was determined. Results of a prior experiment on the CBB's life cycle performed at the same places gave a duration between eight and nine days for the egg stage. Therefore, we chose a value of 8.5 days as the average incubation period. Then, from the number of eggs counted in each sample and the beginning of oviposition date for each treatment, it was possible to estimate the number of eggs laid in each sampling interval assuming a constant daily rate of laying. Thus, the number of eggs counted in the first sample was divided by the number of days from the beginning of oviposition until the date of first sampling in order to obtain a daily rate. Then, from the number of eggs counted on the second sample we subtracted the number of eggs counted on the previous sample that would not have hatched in the intervening period, assuming an incubation period of 8.5 days. The remaining "new" eggs were converted to a daily rate as before. This calculation was made iteratively for all subsequent samples using a spreadsheet. From the $m x$ value was subtracted a value of $10 \%$, assuming a sex ratio of about ten females: 1 male, because this parameter should represent only the female offspring produced. It was assumed for the construction of the life-tables that emerged adults used for infesting berries were all mated females of similar age (initial cohort).

The change in the number of live and dead CBB adults, as well as in the number of female founders that abandoned previously infested berries over time in each treatment and site, was described by fitting the data to a third order polynomial regression: $Y_{t}=\beta_{0}+\beta_{1}^{*} t+\beta_{2}$ $* t^{2}+\beta_{3} * t^{3}+\varepsilon_{t}$, where, $Y_{t}$ is the number of live or dead $\mathrm{CBB}$ adults or the number of borers that abandoned previously infested berries, $t$ is the number of days after infestation with $\mathrm{CBB}$ at each sampling date, and $\beta_{0}, \beta_{1}, \beta_{2}$ and $\beta_{3}$ are fitted coefficients. All fitted coefficients were estimated using the general linear model (GLM) procedure of SAS (SAS Institute, 1989). Differences in abandonment, mortality and survival among treatments and sites were analyzed by comparing the regression coefficients of these polynomials using the contrast method in the GLM procedure of SAS. An F-test was used to evaluate the significance of the differences in estimated coefficients among the regression curves.

Survival curves on tree and ground micro-environments were fitted and then compared using non-parametric tests such as the Wilcoxon rank test and log-rank 
test using the Lifetest procedure of SAS (SAS Institute, 1989). Demographic parameters for the pest on different treatments were compared through exact non-parametric methods using the NPAR1WAY procedure of SAS.

\section{Results and Discussion}

A proportion of founders (CBB females that colonized healthy coffee berries) disappeared from previously perforated berries and in some treatments the proportion of this abandonment was high (Figures 1 and 2). It is not understood what happens to these borers. It is possible that they leave unsuitable infested berries before penetration into the endosperm to search for berries with more favorable conditions for colonization. On the other hand, borers outside the coffee berries are more vulnerable and therefore it is reasonable to assume that pathogens, predators and other factors killed most of them. This abandonment could be therefore considered as an additional cause of unexplained mortality. Baker et al. (1992a) suggest that abandoned perforated fruits may be an additional indication of borer mortality; they also point out that dead immature stages can disappear quickly from the berries due to cleaning activities of the brood performed by the mother.
Neither abandonment rates $\left(F_{1,12}=0.66, p=0.4339\right.$ and $F_{1,12}=0.01, p=0.9285$ for Supía and La Catalina respectively), mortality rates $\left(F_{1,12}=1.07, p=0.3220\right.$ and $F_{1,12}=2.09, p=0.1743$ for Supía and La Catalina respectively) nor survival rates $\left(F_{1,12}=1.63, p=0.2255\right.$ and $F_{1,12}$ $=0.92, p=0.3559$ for Supía and La Catalina respectively) of adult founder females differed between treatments infested at 150, 210 and $240 \mathrm{DAF}$, when the endosperms were sufficiently developed. However, these treatments had significantly lower mortality rates $\left(F_{1,12}=9.01, p=\right.$ 0.0110 and $F_{1,12}=7.96, p=0.0154$ for Supía and La Catalina respectively) and higher survival rates $\left(F_{1,12}=\right.$ $4.90, p=0.0470$ and $F_{1,12}=6.07, p=0.0298$ for Supía and $\mathrm{La}$ Catalina respectively) when compared with the first two treatments (60 and $90 \mathrm{DAF}$ ) as seen in Figures 1 and 2.

Between 120 and 150 DAF the female borer starts to find optimum conditions inside the berry for establishment and reproduction, and she tends to stabilize its death rates because she can penetrate faster into the berry endosperm where deleterious agents have little effect. There is an ever-ascending trend in the number of borers that build oviposition galleries and start laying eggs as the age of berries increases. This agrees with results from Muñoz (1989) who recorded beginning of perforation of berries from $60 \mathrm{DAF}$ in Honduras, but bored endosperms were found only from 100 DAF.
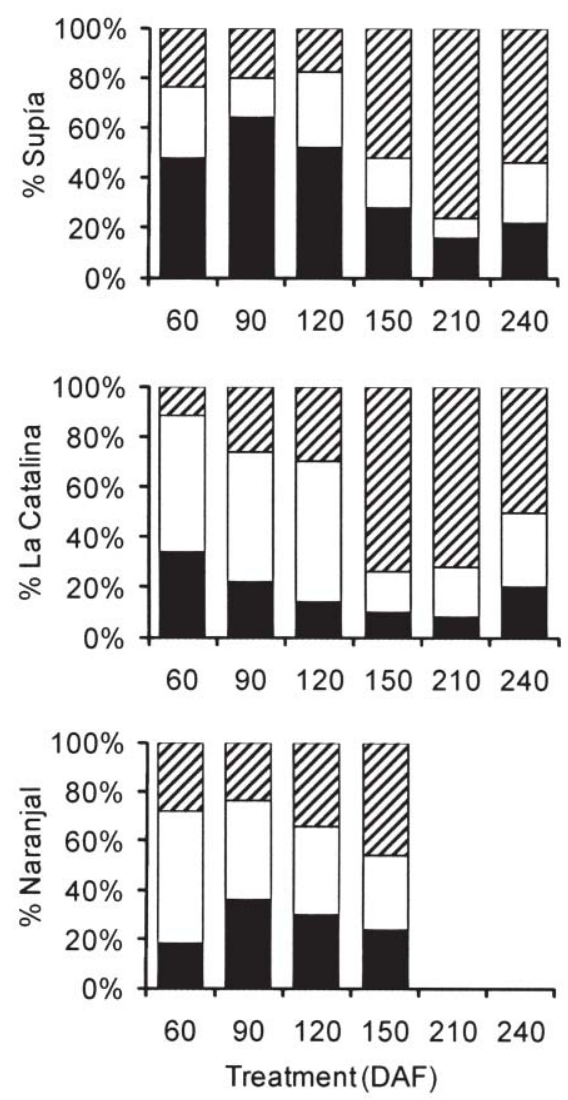
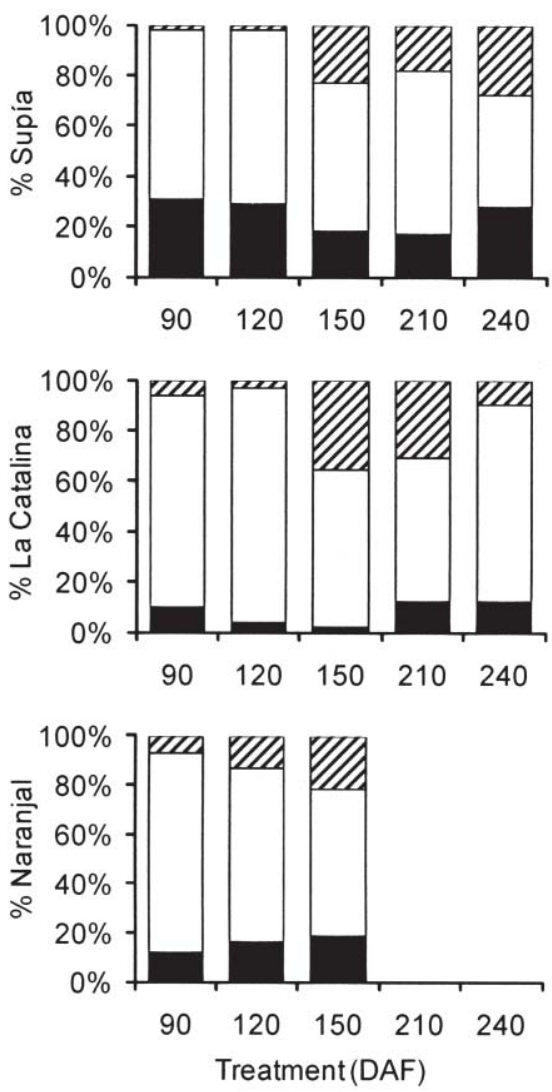

Figure 1 - Percentage histograms for live (striped bars), dead (black bars) and disappeared adults of coffee berry borer (white bars) from infested sampled berries on the trees (left column) and on the ground (right column). DAF = days after flowering. 
Camilo et al. (2003) also reported the first bored endosperms together with the start of oviposition from 112 DAF in Dominican Republic. In Cuba Cintrón-Valdés and Grillo-Rabelo (2006) reported that coffee berries begin to be susceptible to the borer from 107 DAF (with $11 \%$ dry matter), whilst oviposition starts between 137 and $152 \mathrm{DAF}$.

In $97 \%$ of all cases, abandonment of perforated berries occurred before the insect began oviposition, and $81 \%$ of borers left berries before perforating the endosperm. Most of these abandoned berries develop into
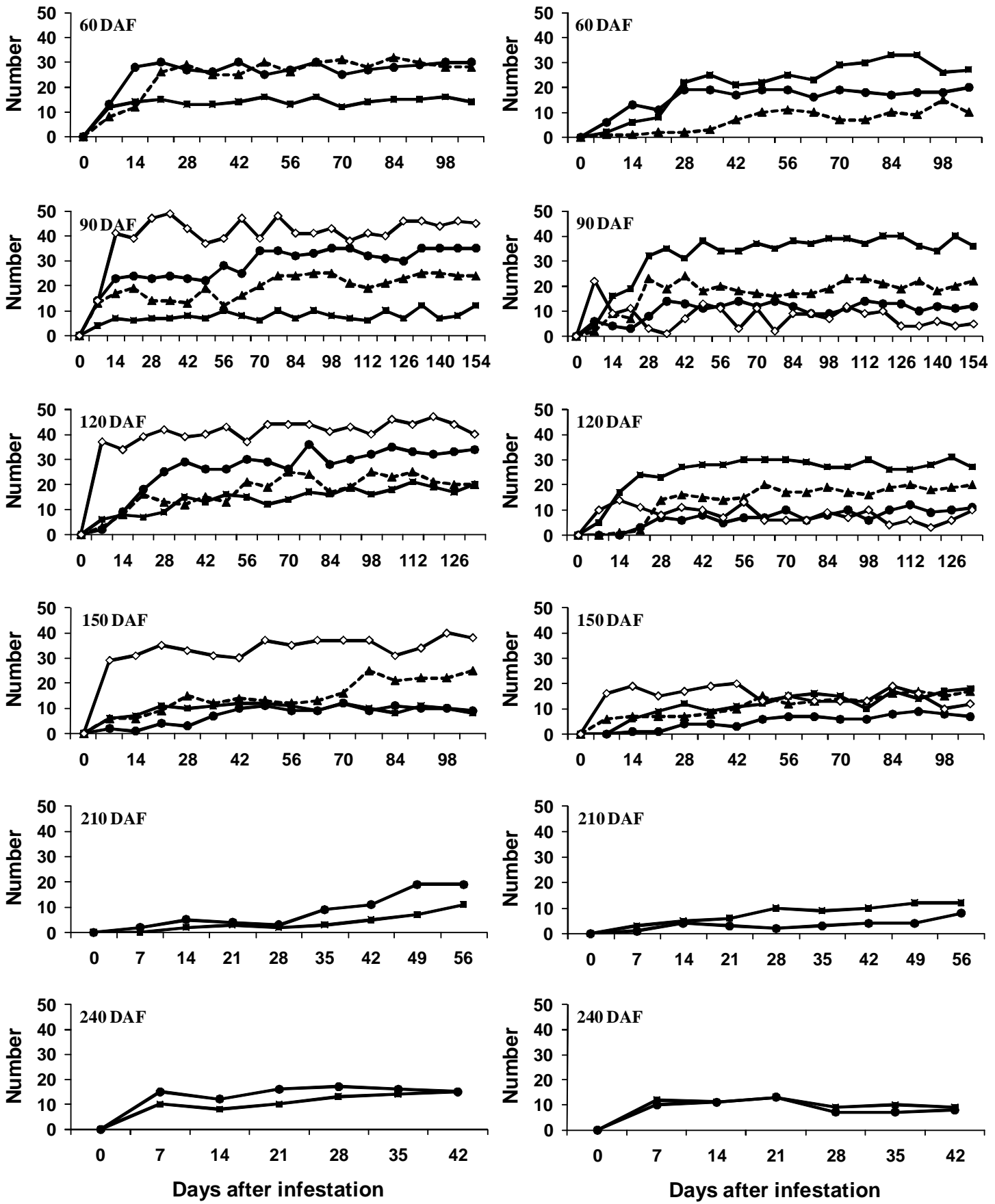

Figure 2 - Number of perforated abandoned berries by H. hampei on trees (left column), and number of dead founders (right column) for each treatment. $(\boldsymbol{\square})$ Supía, $(\diamond)$ El Prado, $(\bullet)$ La Catalina, $(\boldsymbol{\Delta})$ Naranjal. DAF $=$ days after flowering. 
vide a good substrate for the borer. Similar trends were seen on ground berries.

These results are most likely due to the toxic effects of endosulfan sprays in the commercial farm. The above situation, added to an atypical climatic situation during the year of the study were most likely responsible for the abandonment and/or death of borers when they start to perforate the berries, supporting evidence come from Baker et al. (1992a) who reported the highest rate of unpenetrated berries (36.5\%) in Mexico for infestations done during the wet season. Such high abandonment levels in the commercial farm, where chemicals were employed, attest to the lethal effectiveness of endosulfan and provide additional support that much abandonment of berries is linked to mortality.

The highest mortality rates in the experimental stations were found in Supía, which were twice as high as those found in the other two stations for berries infested at $90 \mathrm{DAF}\left(F_{1,39}=7.28, p=0.0113\right), 120 \mathrm{DAF}\left(F_{1,60}=9.72\right.$, $p=0.0028)$ and $150 \operatorname{DAF}\left(F_{1,33}=10.31, p=0.0029\right)$ as seen in Figure 2. This was due to high infection levels of the entomopathogenic fungus $B$. bassiana during the infestation stage, possibly favored by the presence of shade trees in the plot; the other localities had no shade trees and the incidence of direct sunlight might have propitiated unfavorable conditions for the fungus. This result constitutes direct evidence that shade regulation may help regulate $\mathrm{CBB}$ numbers, though it could also have adverse effects (higher levels of fungal diseases of the tree, lower yields, etc.) that need to be studied before commercial recommendations can be made.

Beauveria bassiana turned out to be the main identifiable mortality factor for adult CBB females in natural conditions (it was associated with $97 \%$ of apparent mortality over all experimental stations); however, due to its great capacity for infection, the fungus could also have established on borers that had died from other causes, which would mask their true cause of death. Baker et al. (1992a) found that $63 \%$ of all mortality for adult borers evaluated on berries with hard endosperms above 30 days after infestation in seven experiments carried out in Mexico was due to this fungus; they also pointed out that mortality rates for females was low once they have established inside the endosperm and that most of the time pathogens are the main cause of death. Natural occurrence of $B$. bassiana is prevalent in CBB populations where no B. bassiana has ever been applied (Monzón et al., 2008). They pointed out that infection levels of the fungus vary considerably throughout a season and between years, and infection levels up to $44 \%$ can be found in unsprayed fields. A longer study under local conditions is needed to determine the effect of this fungus over more than one season and under different shade regimes.

The duration of the pre-oviposition period was strongly influenced by the consistency of berries (Figure 3); longer periods for early ages of fruits (60 and 90 $\mathrm{DAF}$ ) indicate the inactivity of the pest in these immature berries, which are used in most cases as a refuge rather than as a host for multiplication. This behavior is consistent with reports from Montoya-Osorio and Cárdenas-Murillo (1994) and Sreedharan et al. (1994). Thus it is improbable that under Colombian field conditions egg laying is initiated from as soon as the second day after attack, as in reports of Baker et al. (1992a) in Mexico.

The oviposition capacity rose in relation to the level of accumulated dry matter in all experimental stations until 210 DAF (Figure 4). The curves of mean accumulated egg hatching over time were well fitted by a second order polynomial regression model, $r^{2}=0.9971$. No differences in regression coefficients were found for curves at 210 and $240 \mathrm{DAF}\left(F_{1,17}=1.64, p=0.2175\right)$, but differences were found between curves at 120 and 150 DAF when compared with those at 210 and $240 \mathrm{DAF}$ $\left(F_{1,17}=81.57, p<0.0001\right)$. Differences were also found between egg curves at 120 and $150 \mathrm{DAF}\left(F_{1,17}=12.63\right.$, $p=0.0024)$ as egg production was higher at $120 \mathrm{DAF}$ from 42 days after infestation. This result agrees with

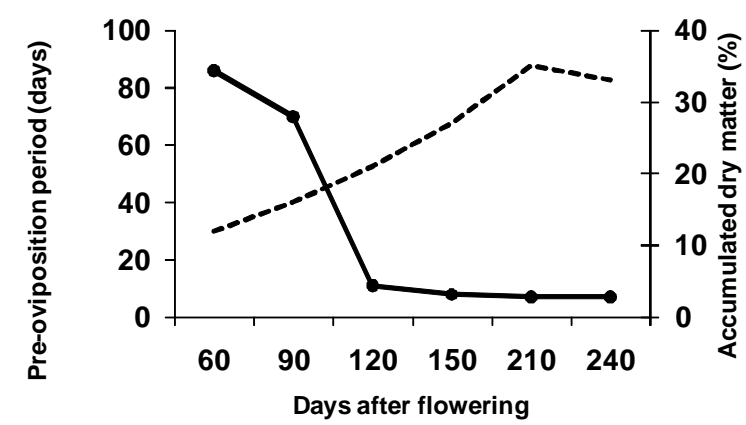

Figure 3 - Pre-oviposition period of $H$. hampei (solid line) and berry dry matter (dashed line) over time according to coffee berry age and consistence.

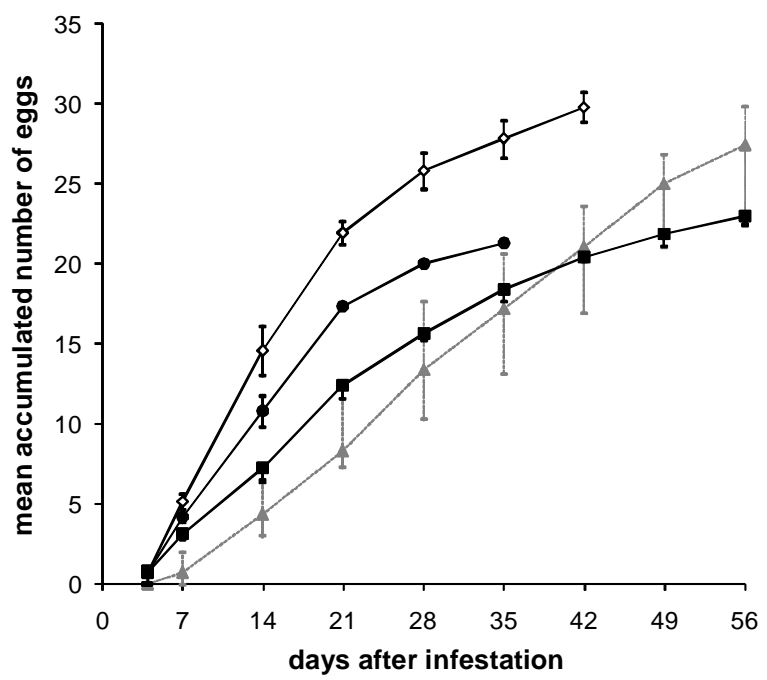

Figure 4 - Mean accumulated number of eggs produced per $H$. hampei females in berries on the trees for the different treatments: $(\Delta) 120 \mathrm{DAF},(\boldsymbol{\square}) 150 \mathrm{DAF}$, $(\diamond) 210 \mathrm{DAF},(\bullet) 240 \mathrm{DAF}$. Vertical bars represent minimum and maximum values. 
Gaviria et al. (1995) who found that the number of eggs laid is strongly influenced by the stage of physiological development of the berries. Lower values found in treatment 7 (240 DAF) might be due to deterioration of the overripe berries, perhaps the high dry weight makes it less suitable for development of the brood or a build-up of secondary plant substances start to cause antibiosis.

The average number of all developmental stages produced from a founder female over time followed a similar pattern as observed in the curves of accumulated oviposition, that is, no difference was found among experimental stations, but there were marked differences between treatments (Figure 5). Thus berries infested at 60 and $90 \mathrm{DAF}$, which had the lowest values due to its unsuitability for borer reproduction, were different from berries infested at 120 and $150 \operatorname{DAF}\left(F_{1,50}=8.86, p=\right.$ $0.0045)$. In the same way, differences were found between the regression coefficients at 120 and $150 \mathrm{DAF}$ when compared with those at 210 and $240 \mathrm{DAF}$, where the pest is able to express its maximum potential for reproduction $\left(F_{1,50}=9.47, p=0.0034\right)$. Experimental stations were different to the commercial farm as there was no reproduction at all in the latter for the treatments that could be compared (90, 120 and $150 \mathrm{DAF})$.

The pre-reproductive period measured from the appearance of the first eggs to the last day before the egg curve starts to rise again (when oviposition of F1 females begins) for all treatments of this experiment was 49 days approximately. This value was used to estimate the possible number of generations of the pest through a coffee crop cycle. The estimation also was done on the basis of the heat units accumulated for the borer throughout the season, according to a base temperature of $16.5^{\circ} \mathrm{C}$ and knowing from a preliminary experiment that approximately 245 accumulated day-degrees are necessary for $50 \%$ of the population to complete the pre-reproductive period. The number of generations that the borer could hypothetically complete from the infestation of

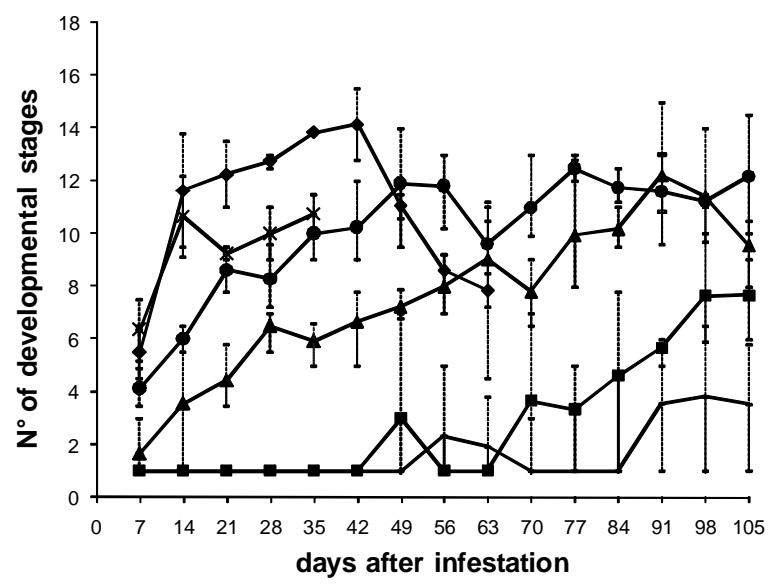

Figure 5 - Average number of developmental stages produced by $H$. hampei in berries. on the trees for each treatment: $(-) 60 \mathrm{DAF},(\boldsymbol{\square}) 90 \mathrm{DAF},(\mathbf{\Delta}) 120 \mathrm{DAF}$, (•) $150 \mathrm{DAF},(\bullet) 210 \mathrm{DAF},(\times) 240 \mathrm{DAF}$. Vertical bars represent minimum and maximum values. berries to ripeness of fruits ( 32 weeks after flowering) and to the last day of the year (three months after ripeness) is summarized in Figure 6, as a simulation for estimating what would happen inside fruits that are not opportunely removed.

No more than two generations of the insect are possible before harvest and not more than 3.5 generations until the end of the year. This contrasts with reports from Brazil, Cameroon, Ivory Coast, Jamaica, Kenya and Uganda that mention seven to eight generations of $H$. hampei in a year (Le Pelley, 1968). According to CintrónValdés and Grillo-Rabelo (2006), in Cuba the insect is able to complete three generations before harvest. Thus CBB populations in Colombia do not multiply as fast as many farmers, extensionists and scientists suppose and these results suggest that the opportune collection of berries during harvest aiming at interrupting the reproductive cycle of borers may well be the most cost effective option. If this practice is not carried out by the end of the year the number of generations would be twice those of harvest time, which would increase dramatically the infestation level of the pest (Figure 6). These estimates suppose that the borers do not leave the natal berries; bearing in mind the time that the insects invest in locating a new suitable berry for its reproduction, the mean number of generations that could really occur would be somewhat lower.

Development of borer populations in this environment was affected by a prolonged rainy period that was present in almost every age of infestation. In fact, the accumulated rainfall from April to June in 1995, which coincided with the establishment of the first four treatments $(60,90,120$ and $150 \mathrm{DAF})$, was $500 \mathrm{~mm}$ above the historical mean for this period. The usual drier period between June and August was also absent (Figure 7). This weather condition probably lead to a higher decomposition of berries placed on the ground compared with those in coffee trees, as well as to the proliferation of numerous organisms including fungi, bacteria and insects such as ants and some Coleoptera, which would compete for space and/or food. This situation probably increased the abandonment and/or death of founder bor-

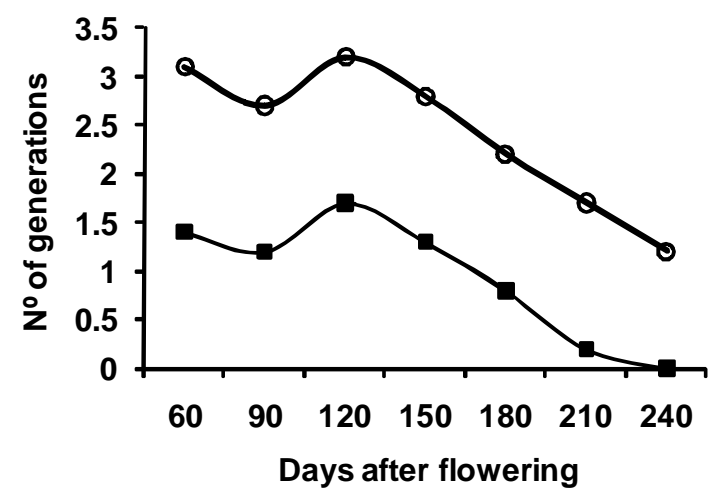

Figure 6 - Number of generations of $H$. hampei until harvest (black squares) and until the end of the year (empty circles) according to the age of infested berries. 
ers in all berries placed on the ground for all treatments and localities when compared with those in the coffee trees (Figure 1). According to Damon (2000), the decomposition of fallen berries by bacteria, fungi and nematodes may result in the death of the borers living in that berries or promote its migration. These results also agree with Teixeira et al. (2006), who state that frequent rainfall and areas where water remains accumulated on the surface of soil make for difficult conditions for the proliferation of the pest in fallen berries.

No borers at all were found on berries evaluated after an average period of 58 days on the ground ( 70 days after infestation) for all treatments and sites. Similarly, it was not possible to find immature stages of the insect in berries infested at 60 and $90 \mathrm{DAF}$; some berries of treatment 3 (120 DAF) had already a few eggs when they were placed on the ground, but immature stages were completely absent when dissected 28 days later.

Only eggs laid inside berries of treatment 4 (150 DAF) were able to develop a complete biological cycle on the ground and to generate new individuals, but even there, after 70 days of being placed on the ground it was

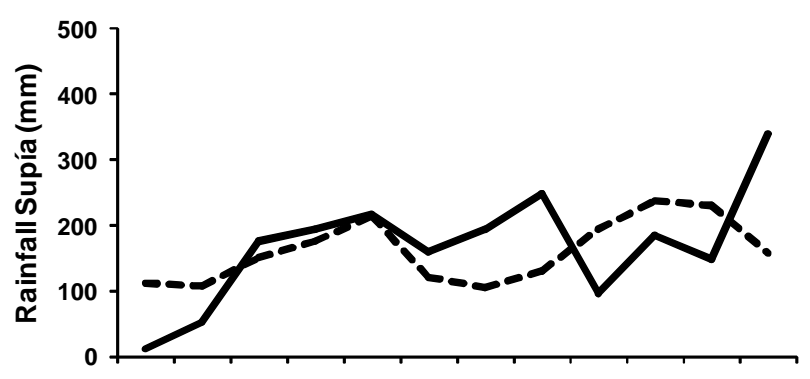

Jan Feb Mar Apr May Jun Jul Aug Sep Oct Nov Dec
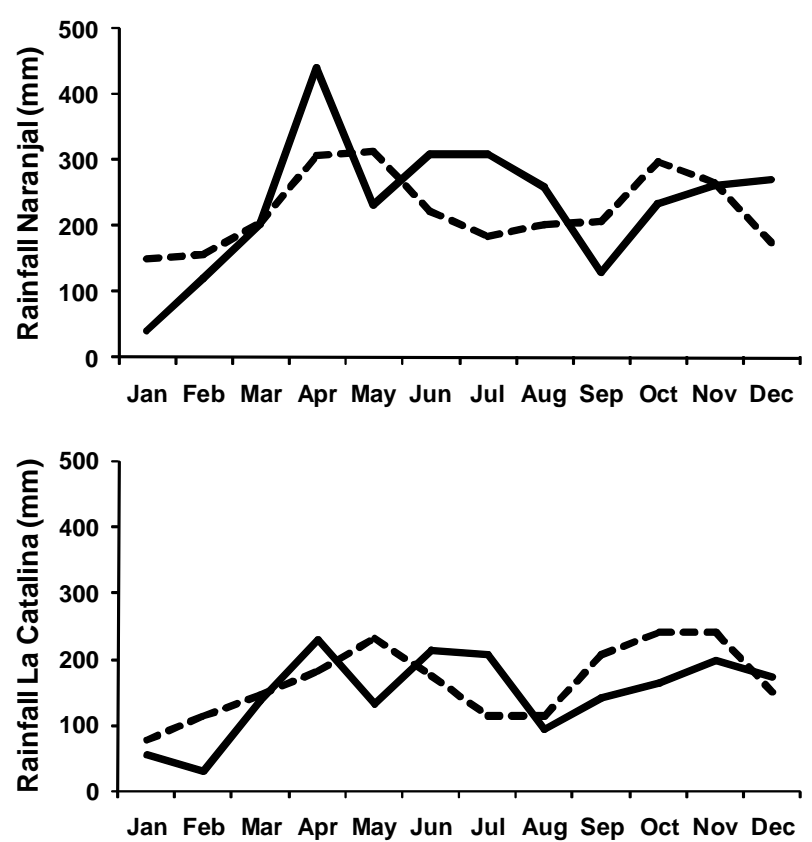

Figure 7 - Historical (dashed lines) vs. recorded rainfall (solid lines) in the experimental stations for 1995. not possible to find any developmental stage of the pest, which means that only one generation was completed and the second generation failed to establish. This last treatment (150 DAF) was the only one that could be compared with its equivalent in tree berries and in this case, no differences between the two micro-environments were found as to the number of developmental stages $\left(F_{1,50}=0.53, p=0.4713\right)$ and alive adults for the founder generation $\left(F_{1,72}=0.24, p=0.6275\right)$. Mortality in ground berries was much higher than that found in a similar experiment under dry season conditions in Mexico (Baker et al., 1992a).

Penados and Ochoa (1977) and Mathieu et al. (1997) have demonstrated that females may delay oviposition as a mechanism of adaptation under unfavorable conditions. Klein-Koch et al. (1988) found that in a high rainfall zone of Ecuador ( $3300 \mathrm{~mm}$ year $^{-1}$ ) more than $80 \%$ of bored berries fallen to the ground were rotted and with a very low population of borers; ripe and overripe berries were the most affected. Emergence of borers from infested berries at high humidities was also reported by Baker et al. (1992b) to avoid problems of pathogens such as $B$. bassiana or to look for more suitable berries for reproduction. According to this it is feasible also to think that extreme climatic conditions or colonizing organisms could kill and/or remove borers from the infested berries.

Survival functions $(l x)$ shown in Figure 8 demonstrate how the probability of survival of the borers increases both in coffee trees and on the ground as they infest older berries whose endosperms are more developed. The statistical comparison of these functions did not show survival differences (Wilcoxon test, $p>0.05$ ) between the two environments for all treatments in Supía; but they did for La Catalina for treatments 2 and 4 (90 and 150 DAF, respectively), where it was greater on the ground, and in Naranjal for treatment 2 (greater in berries on coffee trees), although this is probably more related to atypical environmental factors present in that year (mainly precipitation and humidity), than with factors related to the phenology of berries or with the insect itself.

There is a positive relationship between the age of berries at infestation and the intrinsic rate of increase $(r)$ of the population; whilst generation time $(T)$ and doubling time $(D T)$ tend to be inversely related to the age of berries (Table 2). Negative values of these parameters for the first treatment $(60 \mathrm{DAF})$ indicate that in berries at that age the $\mathrm{CBB}$ population diminishes instead of increasing. The different environmental conditions of the study sites evaluated did not have an important impact on demographic parameters found, as their values were very similar between stations (Table 2). However, differences were evident between treatments, with life history parameters at 60 and $90 \mathrm{DAF}$ being different of those at 120, 150 and 210 DAF ( $p<0.05$ on Savage test).

There are very few published studies on population parameters under field conditions for this species. Baker

Sci. Agric. (Piracicaba, Braz.), v.67, n.6, p.658-668, November/December 2010 

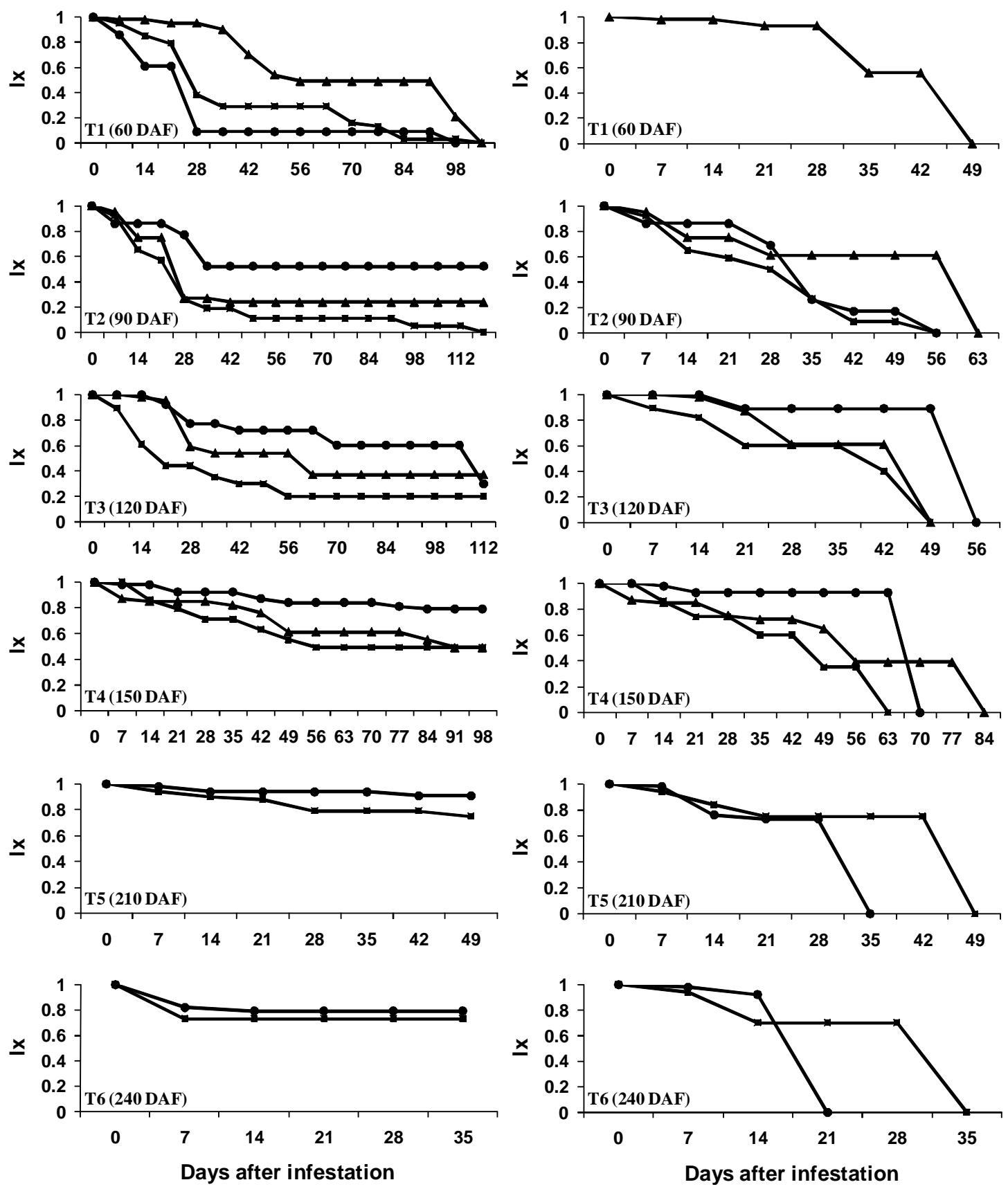

Figure 8 - Survival functions for $H$. hampei in berries on the trees (left column), and on the ground (right column) for each

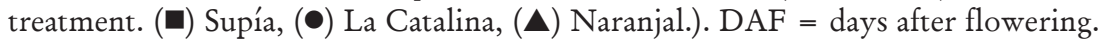

et al. (1992a) reported in Mexico values of $r=0.065, \lambda$ $=1.067, D T=10.7$ days and $T=44.7$ days at $26^{\circ} \mathrm{C}$; Johanneson and Mansingh (1984) found out in Jamaica a mean generation time of $39 \pm 3.5$ days on ripe berries and $43 \pm 4.6$ days on hard green berries. Under laboratory conditions $\left(27 \pm 1^{\circ} \mathrm{C}\right.$ and $\left.85 \% \mathrm{RH}\right)$, Portilla-Reina (1999) and Portilla-Reina and Streett (2006) reported the following ranges for the main life history parameters of CBB females reared at three artificial diets: $R o:(21.76$, 29.25); DT: (48.4, 51.5), $r$ : (0.064, 0.074); $\lambda$ : (1.066, 1.076). Also under controlled conditions, Romero and Cortina
(2007) found differences in these parameters for borers reared in berries of three coffee accessions. They reported values of $R o:(14.6,18.0,25.5)$; $r$ : (0.057, 0.065, $0.073)$; $T:(47.1,44.4,44.6)$ and $D T:(12.2,10.6,9.5)$ for borers reared in Coffea liberica, C. arabica CCC 534 and C. arabica var. Caturra, respectively.

Apart from the consistency of berries, it is important to consider the influence that environmental factors may have on CBB multiplication rates. Baker et al. (1994) found that adults of $\mathrm{CBB}$ could double their mean survival time in laboratory conditions by increasing the rela- 
Table 2 - Population parameters for H. hampei in coffee berries infested on the trees.

\begin{tabular}{lcccccc}
\hline Location & Treatment (DAF) & Ro & $\mathrm{T}$ & $\mathrm{r}$ & $\lambda$ & $\mathrm{DT}$ \\
\hline \multirow{3}{*}{ Naranjal } & 90 & 6.47 & 126.8 & 0.015 & 1.015 & 474.2 \\
& 120 & 18.54 & 65.5 & 0.046 & 1.047 & 15.0 \\
& 150 & 15.94 & 54.7 & 0.053 & 1.054 & 13.1 \\
\hline \multirow{3}{*}{ La Catalina } & 90 & 14.09 & 126.5 & 0.021 & 1.021 & 33.2 \\
& 120 & 18.00 & 65.0 & 0.046 & 1.047 & 15.0 \\
& 150 & 17.60 & 52.5 & 0.055 & 1.057 & 12.6 \\
& 210 & 27.94 & 54.3 & 0.065 & 1.070 & 10.7 \\
\hline \multirow{3}{*}{ Supía } & 60 & 0.69 & 140.2 & -0.003 & 0.997 & -266.6 \\
& 90 & 2.21 & 117.8 & 0.002 & 1.002 & 152.8 \\
& 120 & 13.97 & 60.1 & 0.048 & 1.049 & 14.5 \\
\hline El Prado & 150 & 15.34 & 50.9 & 0.054 & 1.055 & 12.9 \\
\hline DAF & 210 & 23.91 & 48.5 & 0.066 & 1.068 & 10.5 \\
\hline
\end{tabular}

$\mathrm{DAF}=$ days after flowering, $\mathrm{Ro}=$ net reproductive rate, $\mathrm{T}=$ mean generation time, $\mathrm{r}=$ intrinsic rate of natural increase, $\mathrm{DT}=$ doubling time.

tive humidity from $84 \%$ to $93.5 \%$ and that the number of immature stages was two to five times larger at $93.5 \%$ than at $78 \%$. Bergamin (1943) also cited that low temperatures have a certain detrimental action on the oviposition activity of borers. However, it seems that initial variations in the range of different multiplication rates have little effect on the overall growth of the population across the time, since the reproduction rate of the insects tends to be similar once attacked fruits reach an optimum consistency and in field conditions, CBB founder females have considerable ability to find berries with consistent endosperms (Baker, 1999). Finally, according to Armstrong (1978), the rate at which the progeny of an individual is produced, does not directly influence the probability of success in a colonization process, and the intrinsic rate of increase $r$ may be unreliable as a general predictor of colonizing ability.

Our results suggest that under periods of high rainfall it is not cost-effective to collect bored berries on the ground since they will rot quickly and not provide a suitable substrate for the development of CBB populations. Possible manipulation of environmental factors such as shade regimes, coffee varieties and cultural practices aimed to promote suitable conditions to the natural control of borer populations could also be useful for organic coffee producers and it is a field to be explored.

Data obtained with this study have been incorporated into a simulation model of population dynamics of the pest (Leach et al., 1999), which simulated commercial conditions for a Colombian farm and the effect of different flowering patterns and climate conditions on CBB populations.

The increasing reality of climate change means more chaotic weather patterns in the future and through a longer series of life-table studies that traverse a range of climatic conditions, including El Niño and La Niña events, it should be possible to develop a model that helps farmers and extensionists predict upsurges in $\mathrm{CBB}$ population with more precision.

\section{Acknowledgements}

To DFID, UK for financial support, and to field and laboratory assistants, as well as to two anonymous referees for their valuable suggestions that greatly improved the final version of the paper.

\section{References}

Arcila-Pulgarin, J.; Jaramillo-Robledo, A.; Baldion, R.V.; BustilloPardey, A.E. 1993. Flowering of Coffee Plants and its Relation to the Control of Coffee Berry Borer. Cenicafé, Chinchiná, Caldas, Colombia. (Avances Técnicos Cenicafé, 193. (in Spanish).

Armstrong, R.A. 1978. A note on the demography of colonization. The American Naturalist 112: 243-245.

Baker, P.S. 1999. The coffee berry borer in Colombia. Final report of the DFID-Cenicafé-CABI Bioscience IPM for coffee project (CNTR 93/1536A). DFID-Cenicafé, Chinchiná, Colombia.

Baker, P.S.; Barrera, J.F.; Rivas, A. 1992a. Life-history studies of the coffee berry borer (Hypothenemus hampei, Scolytidae) on coffee trees in Southern Mexico. Journal of Applied Ecology 29: 656-662.

Baker, P.S.; Ley, C.; Valbuena, R; Barrera, J.F. 1992b. Factors affecting the emergence of Hypothenemus hampei (Coleoptera:Scolytidae) from coffee berries. Bulletin of Entomological Research 82: 145-150.

Baker, P.S.; Rivas, A.; Valbuena, R.; Ley, C.; Barrera, J.F. 1994. Abiotic mortality factors of the coffee berry borer (Hypothenemus hampei). Entomologia Experimentalis et Aplicata 71: 201-209.

Bergamin, J. 1943. Contribution to the biology knowledge of coffee berry borer Hypothenemus hampei - (Ferr) (Coleoptera:Ipidae). Arquivos do Instituto Biológico 14: 3172. (in Portuguese).

Camayo-Vélez, G.C.; Arcila-Pulgarín, J. 1997. Flower Development of Coffee Plants Under Coffee Growing Region's Conditions in Colombia CENICAFÉ, Chinchiná, Caldas. (Avances Técnicos Cenicafé, 245). (in Spanish). 
Camilo, J.F.; Olivares, F.F.; Jiménez, H.A. 2003. Phenology and reproduction of the coffee borer (Hypothenemus hampei Ferrari) during the fruit growth. Agronomía Mesoamericana 14: 59-63. (in Spanish, with abstract in English).

Carey, J.R. 1993. Applied Demography for Biologist With Special Emphasis on Insects. Oxford University Press, New York, NY, USA.

Cintrón-Valdés, B.; Grillo-Ravelo, H. 2006. Characterization of coffee berry borer population dynamics (Hypothenemus hampei (Ferrari) (Curculionidae: Scolytinae) during fruit growth. Centro Agrícola 33: 55-60. (in Spanish, with abstract in English).

Damon, 2000. A. A review of biology and control of the coffee berry borer Hypothenemus hampei (Coleoptera:Scolytidae). Bulletin of Entomological Research 90: 453-465.

Dublin, L.I.; Lotka, A.J. 1925. On the true rate of natural increase. Journal of the American Statistical Association 20: 305-339.

Duque-Orrego, H.; Márquez-Quintero, A.; Hernández-S, M. 2002. Case studies on integrated management costs for coffee berry borer in Risaralda state, Colombia. Cenicafé 53: 106-118. (in Spanish, with abstract in English).

Gaviria, A.M.; Cárdenas, R.; Montoya, E.C.; Madrigal, A. 1995. Increase of coffee berry borer populations, Hypothenemus hampei (Ferrari) related to the development of coffee fruits. Revista Colombiana de Entomología 21: 145-151. (in Spanish, with abstract in English).

Jaramillo, J.; Borgemeister, C.; Baker, P. 2006. Coffee berry borer Hypothenemus hampei (Coleoptera: Curculionidae): searching for sustainable control strategies. Bulletin of Entomological Research 96: 223-233.

Johanneson, N.E., Mansingh, A. 1984. Host-pest relationship of the genus Hypothenemus (Coleoptera: Scolytidae) with special reference to the coffee berry borer, $H$. hampei. Journal of Coffee Research 14: 43-56.

Klein-Koch, C.; Espinoza, O.; Tandazo, A.; Cisneros, P.; Delgado, D. 1988. Natural factors of regulation and biological control of the coffee berry borer (Hypothenemus hampei). Sanidad Vegetal 3: 5-30. (in Spanish).

Le Pelley, R.H. 1968. The Pests of Coffee. Longmans Green, London, UK.

Leach, A.W., Stonehouse, J.M.; Baker, P.S. 1999. A population and management model of the coffee berry borer, Hypothenemus bampei, to evaluate the returns of different integrated management strategies in Colombian coffee. p. 173-180. In: Thomas, M.B.; Kedwards, T., eds. Aspects of applied biology 53: challenges in applied population biology. Association of Applied Biologists, Wellesbourne, Warwick, UK.

Lee, E.T.; Wang, J.W. 2003. Statistical methods for survival data analysis. 3ed. Wiley-Interscience, New York, NY, USA.
Mathieu, F.; Brun, O.; Frerot, B. 1997. Factors related to native host abandonment by the coffee berry borer Hypothenemus hampei (Ferr.) (Col., Scolytidae). Journal of Applied Entomology 121: $175-180$.

Montoya-Osorio., S.A.; Cárdenas-Murillo., R. 1994. The biology of Hypothenemus hampei (Ferrari) on coffee fruits of different developmental stages. Cenicafé 45: 5-13. (in Spanish, with abstract in English).

Monzón, A.J.; Guharay, F.; Klingen, I. 2008. Natural occurrence of Beauveria bassiana in Hypothenemus hampei (Coleoptera: Curculionidae) populations in unsprayed coffee fields. Journal of Invertebrate Pathology 97: 134-141.

Muñoz, R. 1989. Biological cycle and parthenogenetic reproduction of coffee berry borer Hypothenemus hampei Ferrari. Turrialba 39: 415-421. (in Spanish, with abstract in English).

Penados, R.; Ochoa, H. 1977. Consistency of coffee berries and its importance in controlling the coffee berry borer Hypothenemus hampei Ferr. Revista Cafetalera 168: 36-38. (in Spanish).

Portilla-Reina, M. 1999. Development and evaluation of an artifitial diet for rearing Hypothenemus hampei. Cenicafé 50: 24-38. (in Spanish, with abstract in English).

Portilla-Reina, M.; Streett, D. 2006. New techniques of automated mass rearing of Hypothenemus hampei on a modified "Cenibroca" artifitial diet. Cenicafé 57: 37-50. (in Spanish, with abstract in English).

Rabinovich, J.E. 1980. An introduction to the ecology of animal populations. Compañía Editorial Continental, Mexico city, México (in Spanish).

Romero, J.V.; Cortina, H.A. 2007. Life tables of Hypothenemus hampei (Coleoptera: Curculionidae: Scolytinae) on three coffee accessions. Revista Colombiana de Entomología 33: 10-16. (in Spanish, with abstract in English).

SAS Institute. 1989. SAS/STAT User's Guide, Version 6. 4ed. v2. SAS Institute, Cary, NC, USA.

Sreedharan, K.; Balakrishnan, M.M.; Prakasan, C.B.; Krishnamoorthy, B.P.; Naidu, R. 1994. Bio-ecology and management of coffee berry borer. Indian Coffee 58: 5-13.

Teixeira, C.A.D.; Souza, O.; Costa, J.N.M. 2006. "Conilon" coffee berries bored by Hypothenemus hampei (Ferrari) (Coleoptera: Scolytidae): what matters if they drop down during the fruiting phase? Neotropical Entomology 35: 390-394. (in Portuguese, with abstract in English).

Received March 18, 2008

Accepted August 30, 2010 